\title{
Pseudo-Wellens syndrome from sepsis-induced cardiomyopathy: a case report and review of the literature
}

\author{
Teressa Reanne Ju ${ }^{* *}$ (D) Illhwan Yeo ${ }^{2}$, Gregory Pontone ${ }^{2}$ and Reema Bhatt ${ }^{2,3}$
}

\begin{abstract}
Background: Pseudo-Wellens syndrome is a rare entity characterized by the presence of electrocardiogram (ECG) changes of Wellens syndrome but without the stenosis of the left anterior descending (LAD) coronary artery. In previous reports, pseudo-Wellens syndrome most commonly resulted from recreational drug use or unidentified etiologies. We present a unique case of pseudo-Wellens syndrome due to sepsis-induced cardiomyopathy and a review of the literature.

Case presentation: A 62-year-old Caucasian woman was admitted for sepsis from left foot cellulitis. Laboratory data were notable for elevated lactate of $2.5 \mathrm{mmol} / \mathrm{L}$ and evidence of acute kidney injury. She developed chest pain on the third day of hospitalization. ECG showed symmetric T-wave inversion in leads V1-V4. Serial troponin I levels were within normal limits. Chest imaging showed no pulmonary embolism. Echocardiogram showed ejection fraction of $25 \%$, left ventricular diastolic diameter of $4.6 \mathrm{~cm}$, and multiple segmental wall motion abnormalities. Cardiac catheterization showed patent coronary arteries. The hospital course was complicated by transient sinus bradycardia and hypotension. She was hospitalized for a total of 17 days. ECG prior to discharge showed resolution of T-wave changes.

Conclusion: Pseudo-Wellens syndrome may result from myocardial ischemia due to vasospasm or myocardial edema from external insults. In our case, we suspect sepsis-related cytokine production resulting in cardiomyopathy and pseudo-Wellens syndrome. The clinical manifestations were indistinguishable between Wellens and pseudoWellens syndrome. Physicians should include the diagnosis of pseudo-Wellens syndrome when considering the presence of LAD coronary artery occlusion given risk stratifications.
\end{abstract}

Keywords: Wellens syndrome, Pseudo-Wellens syndrome, Coronary artery disease, Heart failure, Sepsis

\section{Background}

Wellens syndrome is an electrocardiographic (ECG) pattern of T-wave changes that indicates critical stenosis of the left anterior descending (LAD) coronary artery and warrants urgent intervention. Several conditions can mimic Wellens syndrome, such as cocaine use [1], marijuana use [2], myocardial bridging [3], and pulmonary

\footnotetext{
*Correspondence: tej9016@nyp.org

${ }^{1}$ Department of Internal Medicine, NewYork-Presbyterian Queens, Flushing, USA

Full list of author information is available at the end of the article
}

embolism [4]. We present a case of pseudo-Wellens syndrome secondary to sepsis. In addition, we summarize the clinical presentations of 21 reported cases and outline the commonality of pseudo-Wellens syndrome.

\section{Case presentation}

A 62-year-old Caucasian woman with a history of stroke, epilepsy, and peptic ulcer disease presented to our emergency department (ED) for increasing swelling and erythema over her left foot despite 7 days of oral antibiotic therapy for cellulitis. She denied fever, chills, and respiratory or gastrointestinal symptoms. She had 
no family history of cardiac diseases, nor did she have any previous cardiac workup or echocardiograms. She was an active smoker with a 50-pack year smoking history and denied alcohol or drug use. Physical examination upon admission was pertinent for erythema, swelling, and tenderness in the left lower extremity. Neurologic examination was intact except for leftsided hemiparesis from a previous stroke. Laboratory tests were notable for lactate of $2.5 \mathrm{mmol} / \mathrm{L}$. Her serum creatinine increased from 0.6 to $0.92 \mathrm{mg} / \mathrm{dL}$ within 24 hours upon admission, consistent with a diagnosis of acute kidney injury. She was hospitalized under the diagnosis of cellulitis complicating sepsis with endorgan dysfunction and started on intravenous vancomycin 1000 mg daily.

She was clinically stable until the third day of hospitalization, when she began to have intermittent episodes of hypoxia with a measured oxygen saturation of $88 \%$, along with substernal chest discomfort. Physical examination was pertinent for diffuse wheezing in all lung fields which was alleviated after receiving nebulized albuterol. The following day, hypotension was noted, with a systolic blood pressure of $75 \mathrm{mmHg}$ that resolved after fluid resuscitation. Her electrocardiogram (ECG) at the time showed sinus tachycardia. Serial troponin I levels were within normal limits. Computed tomography angiogram of the chest was negative for pulmonary embolism. Echocardiogram revealed an ejection fraction of $25 \%$, left ventricular diastolic dimension of $4.6 \mathrm{~cm}$, and multiple segmental wall motion abnormalities in the basal-to-mid anteroseptum along with basal-to-mid anterior, apical anterior, and apical septum.

Repeat ECG 8 hours after the initial one was remarkable for sinus arrhythmia with deep symmetric T-wave inversions in leads V1-V4, consistent with Wellens syndrome (Fig. 1). Emergency cardiac catheterization revealed patent coronary arteries without obstructive coronary artery disease (CAD) (Fig. 2). Following her procedure, she was admitted to a cardiovascular intensive care unit due to alternating episodes of sinus bradycardia and tachycardia accompanied by hypotension which resolved spontaneously without medical management. Her chest pain resolved after day 6 of cardiac catheterization. After 17 days of hospitalization, she was discharged with metoprolol extended-release $25 \mathrm{mg}$ daily, atorvastatin $80 \mathrm{mg}$ daily, and furosemide $20 \mathrm{mg}$ daily. An ECG prior to discharge showed normal sinus rhythm without T-wave abnormalities (Fig. 3). An appointment was made to follow up with our cardiology clinic and a repeat echocardiogram was scheduled. However, she was lost to follow-up, and further attempts to reach the patient by phone were unsuccessful.

\section{Discussion}

The ECG pattern of Wellens syndrome was first described by Gerson et al. in 1979 [5], who noted ECG findings of exercise-induced inverted terminal $\mathrm{T}$ waves in the precordial leads in patients with proximal LAD ischemia. In 1982, de Zwaan and Wellens reported a case

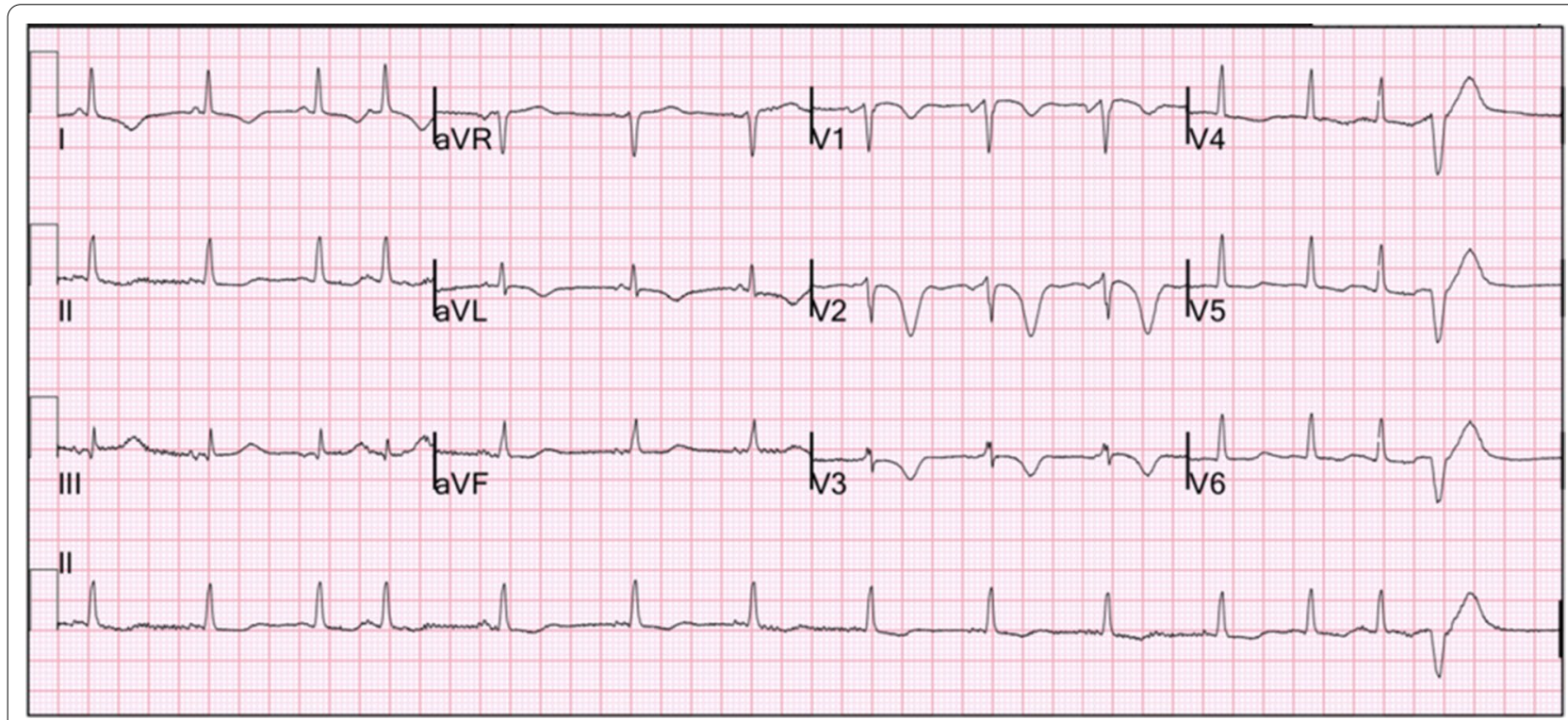

Fig. 1 Electrocardiogram while patient had chest pain: sinus arrhythmia with deep symmetric T-wave inversion in precordial leads V1-V4 consistent with Wellens syndrome 


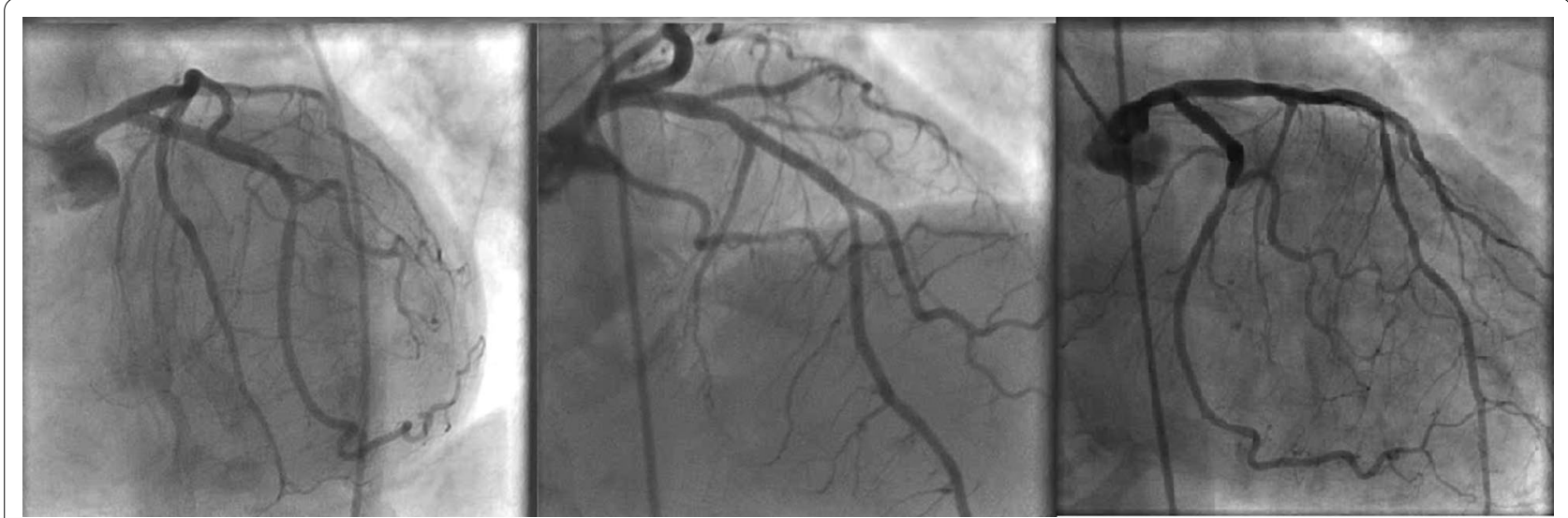

Fig. 2 Cardiac catheterization: patent coronary arteries with mild irregularities in both left anterior oblique-caudal projection (left) and right anterior oblique-cranial projection (middle). The right anterior oblique-caudal projection (right) shows a patent proximal left anterior descending coronary artery

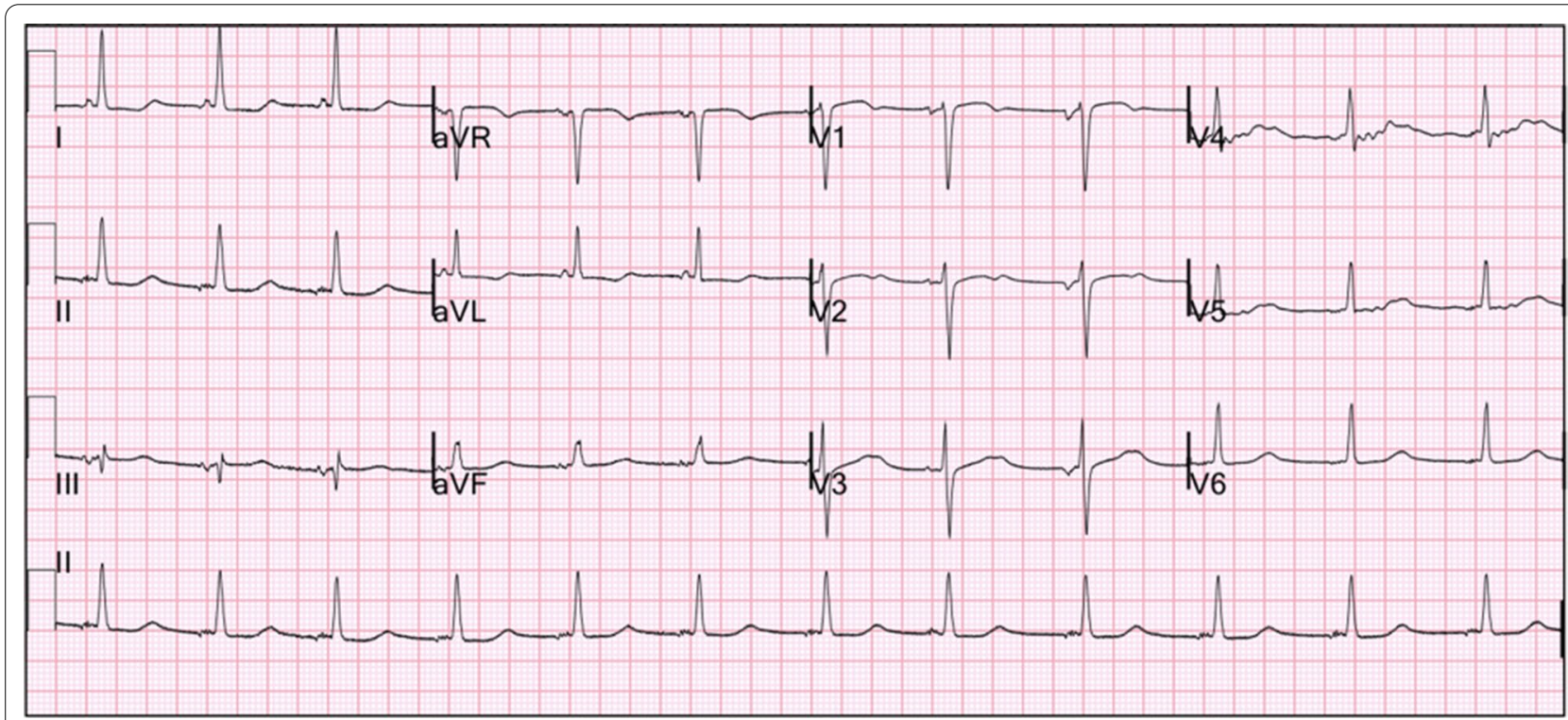

Fig. 3 Electrocardiogram prior to discharge: disappearance of the T-wave inversions after resolution of chest pain

series of 145 patients with unstable angina. Among these patients, 26 (18\%) had similar ECG findings: ST-T segment in leads V2 and V3 consisting of an isoelectric or minimally elevated $(1 \mathrm{~mm})$ takeoff of the ST segment from the QRS complex, a concave or straight ST segment passing into a negative $\mathrm{T}$ wave at an angle of 60 to $90^{\circ}$, and a symmetrically inverted $\mathrm{T}$ wave [6]. In a subsequent prospective study which assessed patients who were admitted due to unstable angina, de Zwaan revealed that 128 of 1260 patients with similar ECG findings all had critical narrowing of the proximal LAD coronary artery [7]. As of today, the criteria for Wellens syndrome are as follows: history of anginal chest pain, minimal or no elevation of cardiac enzymes, no significant ST segment elevation $(<1 \mathrm{~mm})$, no pathological precordial $\mathrm{Q}$ waves, no loss of precordial R-wave progression, and deeply inverted or biphasic $\mathrm{T}$ waves mainly in leads $\mathrm{V} 2$ and V3 and sometimes in leads V1, V4, V5, and V6 $[8,9]$. Wellens syndrome has since been used to identify critical proximal LAD coronary artery stenosis in patients with unstable angina [8].

Pseudo-Wellens syndrome is a term used to describe a constellation of clinical presentations and ECG pattern similar to Wellens syndrome but without the finding of 
Table 1 Reported cases of pseudo-Wellens syndrome in literature

\begin{tabular}{|c|c|c|c|c|c|c|}
\hline Article & Etiology & Age, gender & $\begin{array}{l}\text { Chief complaint, } \\
\text { duration }\end{array}$ & $\begin{array}{l}\text { Reported time of ECG } \\
\text { change resolution }\end{array}$ & $\begin{array}{l}\text { Peak troponin } \\
\text { I level (ng/ml) }\end{array}$ & Angiography finding \\
\hline $\begin{array}{l}\text { Langston et al. } 2006 \\
\text { [10] }\end{array}$ & Cocaine & $46, M$ & $\begin{array}{l}\text { Chest pain, } 45 \text { min- } \\
\text { utes }\end{array}$ & 48 hours & Normal & Normal \\
\hline Batra et al. 2008 [1 1] & Injection drug use & $41, F$ & $\begin{array}{l}\text { Chest pain, several } \\
\text { weeks }\end{array}$ & Not reported & 0.04 & Normal \\
\hline Dhawan et al. 2008 [1] & Cocaine & $41, M$ & Chest pain, 3 hours & 24 hours & Normal & Normal \\
\hline $\begin{array}{l}\text { Bucciarelli-Ducci et al. } \\
2007 \text { [12] }\end{array}$ & Unknown & $73, F$ & SOB, not reported & Persistent at 17 days & 1.1 & $80 \%$ stenosis in RCA \\
\hline $\begin{array}{l}\text { Bucciarelli-Ducci et al. } \\
2007 \text { [12] }\end{array}$ & Unknown & $41, M$ & $\begin{array}{l}\text { Asymptomatic (found } \\
\text { during routine visit) }\end{array}$ & Persistent at 30 days & Normal & $\begin{array}{l}20 \% \text { stenosis in the } \\
\text { mid-LAD coronary } \\
\text { artery } \\
20 \% \text { stenosis in the } \\
\text { mid-RCA }\end{array}$ \\
\hline $\begin{array}{l}\text { Bucciarelli-Ducci et al. } \\
2007 \text { [12] }\end{array}$ & Unknown & $45, M$ & $\begin{array}{l}\text { Chest pain, not } \\
\text { reported }\end{array}$ & 30 days & Normal & Normal \\
\hline $\begin{array}{l}\text { Migliore et al. } 2011 \\
\text { [13] }\end{array}$ & Myocardial bridge & $78, M$ & $\begin{array}{l}\text { Chest pain, not } \\
\text { reported }\end{array}$ & 6 weeks & 3.05 & $\begin{array}{l}\text { Myocardial bridge } \\
\text { in } \angle A D \text { coronary } \\
\text { artery }\end{array}$ \\
\hline $\begin{array}{l}\text { Migliore et al. } 2011 \\
\text { [13] }\end{array}$ & Takotsubo syndrome & $62, F$ & $\begin{array}{l}\text { Chest pain, not } \\
\text { reported }\end{array}$ & 6 weeks & 2.3 & Normal \\
\hline $\begin{array}{l}\text { Migliore et al. } 2011 \\
\text { [13] }\end{array}$ & Acute cholecystitis & $81, \mathrm{~F}$ & $\begin{array}{l}\text { Chest pain, not } \\
\text { reported }\end{array}$ & $\begin{array}{l}\text { Persistent for } 7 \text { days, } \\
\text { resolved after } 6 \\
\text { weeks }\end{array}$ & 2.01 & Normal \\
\hline Abulaiti et al. 2013 [14] & Unknown & $47, M$ & Chest pain, 2 months & $\begin{array}{l}\text { When chest pain } \\
\text { resolved }\end{array}$ & Normal & $\begin{array}{l}50 \% \text { stenosis in } \\
\text { proximal LAD } \\
\text { coronary artery }\end{array}$ \\
\hline Oksuz et al. 2015 [15] & Unknown & $33, M$ & Chest pain, 1 hour & $\begin{array}{l}\text { When chest pain } \\
\text { resolved with nitro- } \\
\text { glycerin }\end{array}$ & Normal & Normal \\
\hline Co et al. 2017 [2] & Marijuana & $22, \mathrm{M}$ & SOB, 5 days & 7 months & Normal & $\begin{array}{l}\text { Angiography is not } \\
\text { performed }\end{array}$ \\
\hline Kaplanis et al. 2017 [3] & Myocardial bridge & $55, M$ & Chest pain, 3 days & Not reported & Normal & $\begin{array}{l}\text { Myocardial bridge } \\
\text { in the mid-LAD } \\
\text { coronary artery }\end{array}$ \\
\hline Lin et al. 2017 [16] & Cocaine & $52, \mathrm{M}$ & Chest pain, 1 day & $\begin{array}{l}\text { When chest pain } \\
\text { resolved }\end{array}$ & Normal & $\begin{array}{l}\text { Non-occlusive } \\
\text { LAD coronary artery }\end{array}$ \\
\hline Inayat et al. 2018 [17] & Cannabis, PCP & $41, M$ & Chest pain, 6 hours & 12 weeks & Normal & Normal \\
\hline Kumar et al. 2018 [18] & Cocaine & $27, \mathrm{M}$ & $\begin{array}{l}\text { Chest pain, not } \\
\text { reported }\end{array}$ & 1 week & Not reported & Not performed \\
\hline Sedhai et al. 2018 [4] & Pulmonary embolism & $22, \mathrm{M}$ & $\begin{array}{l}\text { Chest pain, not } \\
\text { reported }\end{array}$ & Not reported & Normal & Not performed \\
\hline $\begin{array}{l}\text { Grautoff et al. } 2019 \\
\text { [19] }\end{array}$ & Acute cholecystitis & $54, M$ & $\begin{array}{l}\text { Epigastric pain, not } \\
\text { reported }\end{array}$ & Not reported & Not reported & Not performed \\
\hline $\begin{array}{l}\text { Muhailan and Al- } \\
\text { Shbool } 2019 \text { [20] }\end{array}$ & $\begin{array}{l}\text { Nivolumab/ipili- } \\
\text { mumab }\end{array}$ & $70, M$ & Syncope, not reported & 2 weeks & 1.94 & Normal \\
\hline Ola and Tak 2019 [21] & HTN and LVH & $61, M$ & Chest pain, 3 days & $\begin{array}{l}\text { When hypertension } \\
\text { resolved }\end{array}$ & Normal & Normal \\
\hline Effoe et al. 2019 [22] & Acute pancreatitis & $45, M$ & Chest pain, & $\begin{array}{l}\text { When chest pain } \\
\text { resolved ( } 24 \text { hours) }\end{array}$ & Normal & $\begin{array}{l}\text { Anomalous origin of } \\
\text { the dominant RCA } \\
\text { from the opposite } \\
\text { sinus }\end{array}$ \\
\hline $\begin{array}{l}\text { Ju et al. } 2020 \text { (present } \\
\text { case) }\end{array}$ & Sepsis & $62, M$ & Chest pain, one day & 6 days & Normal & Normal \\
\hline
\end{tabular}


critical stenosis of LAD coronary artery. Table 1 summarizes 22 reported cases of pseudo-Wellens syndrome [1$4,10-22]$. The average age was 50 years (range 22-81), and four patients (18.1\%) were female. In six of these cases, illicit drug use such as cocaine and phencyclidine were identified. Five cases had no identified causes. The majority of cases had presenting symptoms of chest pain, while the duration of symptoms varied from a few hours to a few months. Normal to mildly elevated serum cardiac enzymes were noted. Resolution of ECG changes occurred when chest pain resolved in some but not all cases. Coronary angiography was mostly unremarkable. In the absence of existing CAD, pseudo-Wellens syndrome had a favorable prognosis. There was no mortality reported in the cohort.

The exact mechanism of ECG changes in pseudoWellens syndrome is unclear. Historically, ECG findings were explained by transient impedance of coronary flow leading to myocardial ischemia $[10,15]$. As vasospasm resolved, ECG changes recovered to baseline and symptoms resolved. In another study utilizing contrastenhanced cardiac magnetic resonance imaging, Migliore et al. found myocardial edema, rather than ischemia, underlying the Wellens ECG pattern [13]. The ECG pattern was persistently present until myocardial edema resolved. In our case, we postulate myocardial edema as a result of sepsis-related cytokine production, resulting in cardiomyopathy and pseudo-Wellens syndrome [23].

Takotsubo cardiomyopathy and sepsis-induced cardiomyopathy may be difficult to differentiate clinically. However, some differences exist in the pathophysiology and echocardiographic findings between the two entities [24]. Takotsubo cardiomyopathy typically leads to regional wall dysfunction, mostly described as apical ballooning of the distal ventricle with hyperkinesis of the basal walls secondary to catecholamine surge [25]. However, two anatomical variants, hypokinesis of the mid-ventricular segments only and hypokinesis of the basal segments only, account for $15 \%$ and less than $5 \%$ of cases with Takotsubo cardiomyopathy, respectively [26]. The Mayo Clinic criteria for diagnosing Takotsubo cardiomyopathy includes three key components: regional wall motion abnormalities extending beyond a single epicardial vascular distribution; absence of obstructive coronary disease; and presence of electrocardiographic abnormalities [27]. On the other hand, in sepsis-induced cardiomyopathy, the cytokine storm leads to myocardial dysfunction, perhaps caused by mitochondrial dysfunction. This may be displayed as various echocardiographic findings, such as global or regional wall motion abnormalities during systole and/or diastole [24, 28]. The regional wall motion abnormalities in our patient's echocardiograms were located in the territory of the LAD coronary artery.
Therefore, the image findings are inconsistent with the Mayo Clinic definition of Takotsubo cardiomyopathy and more in favor of sepsis-induced cardiomyopathy. Nevertheless, as supportive therapy represents the mainstay of treatment for the sepsis-induced and Takotsubo cardiomyopathies, the distinction in diagnosis should not impact the overall clinical management.

\section{Conclusion}

Pseudo-Wellens syndrome is a rare entity which mimics Wellens syndrome but without the presence of LAD coronary artery stenosis. It likely results from transient myocardial ischemia secondary to vasospasm or myocardial edema due to external insults. While underlying CAD cannot be ruled out based on clinical presentations, physicians should be vigilant to identify ECG pattern of Wellens syndrome and consider early cardiac catheterization to rule out LAD coronary artery pathology.

\section{Abbreviations \\ LAD: Left anterior descending; ECG: Electrocardiogram; CAD: Coronary artery disease. \\ Acknowledgements \\ Not applicable. \\ Authors' contributions \\ TJ: literature search, manuscript drafting, manuscript revision. IY: literature search, manuscript revision. GP: literature search, manuscript revision. RB: manuscript revision, final approval of the version to be published. All authors read and approved the final manuscript.}

Funding

Not applicable.

Availability of data and materials

Not applicable.

\section{Declarations}

Ethics approval and consent to participate Not applicable.

\section{Consent for publication}

Written informed consent was obtained from the patient for publication of this case report and any accompanying images. A copy of the written consent is available for review by the Editor-in-Chief of this journal.

\section{Competing interests}

The authors declare that they have no competing interests.

\section{Author details}

${ }^{1}$ Department of Internal Medicine, NewYork-Presbyterian Queens, Flushing, USA. ${ }^{2}$ Department of Cardiology, NewYork-Presbyterian Queens, Flushing, USA. ${ }^{3}$ Department of Cardiology, Weill Cornell Medicine, New York, USA.

Received: 15 September 2020 Accepted: 23 February 2021

Published online: 06 April 2021 


\section{References}

1. Dhawan SS. Pseudo-Wellens' syndrome after crack cocaine use. Can J Cardiol. 2008;24(5):404

2. Co MLF, Das A, Okwuosa T. Pseudo-Wellens syndrome after heavy marijuana use. Cleve Clin J Med. 2017;84(8):590-1.

3. Kaplanis I, Michas G, Arapi S, Thomopoulos T, Stougiannos P, Trikas A. Myocardial bridge as a cause of pseudo-Wellens' syndrome. Hellenic J Cardiol. 2017;58(6):453-5.

4. Sedhai YR, Basnyat S, Bhattacharya PT. Pseudo-Wellens' syndrome in pulmonary embolism. BMJ Case Rep. 2018;11(1):1-8.

5. Gerson MC, Phillips JF, Morris SN, McHenry PL. Exercise-induced U-wave inversion as a marker of stenosis of the left anterior descending coronary artery. Circulation. 1979:60(5):1014-20.

6. de Zwaan C, Bar FW, Wellens HJ. Characteristic electrocardiographic pattern indicating a critical stenosis high in left anterior descending coronary artery in patients admitted because of impending myocardial infarction. Am Heart J. 1982;103(4 Pt 2):730-6.

7. de Zwaan C, Bar FW, Janssen JH, Cheriex EC, Dassen WR, Brugada P, et al. Angiographic and clinical characteristics of patients with unstable angina showing an ECG pattern indicating critical narrowing of the proximal LAD coronary artery. Am Heart J. 1989;117(3):657-65.

8. Rhinehardt J, Brady WJ, Perron AD, Mattu A. Electrocardiographic manifestations of Wellens' syndrome. Am J Emerg Med. 2002;20(7):638-43.

9. Tandy TK, Bottomy DP, Lewis JG. Wellens' syndrome. Ann Emerg Med. 1999;33(3):347-51.

10. Langston W, Pollack M. Pseudo-Wellens syndrome in a cocaine user. Am J Emerg Med. 2006;24(1):122-3.

11. Batra R, Mishra A, Ng K. Pseudo-Wellens syndrome-a case report. Kardiol Pol. 2008;66(3):340-2.

12. Bucciarelli-Ducci C, Denes P, Holly TA, Wu E. Pseudo Wellens T-waves in patients with suspected myocardial infarction: how cardiac magnetic resonance imaging can help the diagnosis. Int J Cardiol. 2008;128(2):e68-71.

13. Migliore F, Zorzi A, Marra MP, Basso C, Corbetti F, De Lazzari M, et al. Myocardial edema underlies dynamic T-wave inversion (Wellens' ECG pattern) in patients with reversible left ventricular dysfunction. Heart Rhythm. 2011;8(10):1629-34.

14. Abulaiti A, Aini R, Xu H, Song Z. A special case of Wellens'syndrome. J Cardiovasc Dis Res. 2013:4(1):51-4.

15. Oksuz F, Sensoy B, Sen F, Celik E, Ozeke O, Maden O. "Action potential-like" ST elevation following pseudo-Wellens' electrocardiogram. Indian Heart J. 2015;67(5):472-5.
16. Lin AN, Lin S, Gokhroo R, Misra D. Cocaine-induced pseudo-Wellens' syndrome: a Wellens' phenocopy. BMJ Case Rep. 2017. https://doi.org/10. 1136/bcr-2017-222835.

17. Inayat F, Riaz I, Ali NS, Figueredo VM. Pseudo-Wellens' syndrome secondary to concurrent cannabis and phencyclidine intoxication. BMJ Case Rep. 2018. https://doi.org/10.1136/bcr-2018-225755.

18. Kumar S, Sanchez L, Srinivasamurthy R, Mathias PF. Cocaine-induced electrocardiographic phenomenon. Tex Heart Inst J. 2018;45(4):273-4.

19. Grautoff $S$, Balog M, Winde G. Pseudo-Wellens'syndrome and intermittent left bundle branch block in acute cholecystitis. Am J Emerg Med. 2018;36(7):1323.e1-e6.

20. Muhailan M, Al-Shbool G. Pseudo-Wellens' syndrome temporally associated with immune check point inhibitors use. Am J Med Sci. 2019. https://doi.org/10.1016/j.amjms.2019.07.006

21. Ola O, TakT. Pseudo-Wellens syndrome in a patient with hypertension and left ventricular hypertrophy. Am J Case Rep. 2019;20:1231-4.

22. Effoe VS, O'Neal W, Santos R, Rubinsztain L, Zafari AM. Pseudo-Wellens syndrome, acute pancreatitis, and an anomalous coronary artery: a case report. J Med Case Rep. 2019;13(1):387.

23. Ehrman RR, Sullivan AN, Favot MJ, Sherwin RL, Reynolds CA, Abidov A, et al. Pathophysiology, echocardiographic evaluation, biomarker findings, and prognostic implications of septic cardiomyopathy: a review of the literature. Crit Care. 2018;22(1):112.

24. Sato R, Nasu M. A review of sepsis-induced cardiomyopathy. J Intensive Care. 2015:3:48.

25. Templin C, Ghadri JR, Diekmann J, Napp LC, Bataiosu DR, Jaguszewski M, et al. Clinical features and outcomes of Takotsubo (stress) cardiomyopathy. N Engl J Med. 2015;373(10):929-38.

26. Medina de Chazal H, Del Buono MG, Keyser-Marcus L, Ma L, Moeller FG, Berrocal D, et al. Stress cardiomyopathy diagnosis and treatment: JACC state-of-the-art review. J Am Coll Cardiol. 2018;72(16):1955-71.

27. Scantlebury DC, Prasad A. Diagnosis of Takotsubo cardiomyopathy. Circ J. 2014;78(9):2129-39.

28. Beesley SJ, Weber G, Sarge T, Nikravan S, Grissom CK, Lanspa MJ, et al. Septic Cardiomyopathy. Crit Care Med. 2018;46(4):625-34.

\section{Publisher's Note}

Springer Nature remains neutral with regard to jurisdictional claims in published maps and institutional affiliations.
Ready to submit your research? Choose BMC and benefit from:

- fast, convenient online submission

- thorough peer review by experienced researchers in your field

- rapid publication on acceptance

- support for research data, including large and complex data types

- gold Open Access which fosters wider collaboration and increased citations

- maximum visibility for your research: over 100M website views per year

At BMC, research is always in progress.

Learn more biomedcentral.com/submissions 